\title{
Evaluation on Impact of Use of Urea Briquettes in Combination of Organics on Nutrient Use Efficiency in Irrigated Rice
}

\author{
Rinky Roy*, R.K. Bajpai, Vinay Bachkaiya, Chandan Kumar Roy, \\ Minakshi Sahu, Neha Padhi and Ankita Tirkey
}

College of Agriculture, Indira Gandhi Krishi Vishwavidyalaya, Raipur, Chhattisgarh, India

*Corresponding author

\begin{tabular}{|c|}
\hline Keywords \\
\hline $\begin{array}{l}\text { Nitrogen, NUE, } \\
\text { Nutrient use } \\
\text { efficiency, Urea } \\
\text { briquettes, organics, } \\
\text { FYM, Rajeshwari, } \\
\text { Irrigated rice, } \\
\text { Nitrogen losses, N } \\
\text { uptake }\end{array}$ \\
\hline Article Info \\
\hline $\begin{array}{l}\text { Accepted: } \\
12 \text { November } 2018 \\
\text { Available Online: } \\
10 \text { December } 2018\end{array}$ \\
\hline
\end{tabular}

\section{Keywords}

Nitrogen, NUE, Nutrient use briquettes, organics, FYM, Rajeshwari, Irrigated rice, Nitrogen losses, $\mathrm{N}$

Accepted:

Available Online:

10 December 2018

\section{A B S T R A C T}

Rice (Oryza sativa L.) is one of the most important staple food crops worldwide. Nitrogen $(\mathrm{N})$ is the most important nutrient in irrigated rice cultivation. Current high yields of irrigated rice are often associated with applications of higher doses of fertilizer $\mathrm{N}$, as nearly 30-40 percent of applied nitrogen is actually utilized by the crop; even with the best agronomic practices. It has always been a problem to raise the utilization rate of the rice plant and to increase efficiency of absorbed nitrogen for grain production. Hence, a field experiment was conducted during kharif 2017 at the Research cum Instructional Farm, Indira Gandhi Krishi Vishwavidyalaya, Raipur (C.G) to study the impact of use of urea briquettes in combination with organics in irrigated rice cultivation system with eleven treatments each replicated four times. Rice variety Rajeshwari was taken as test crop under irrigated condition. The experiment laidout in randomized complete block design comprised of four treatments involving application of urea briquettes, another four treatments involving application of urea and rest three treatments involving application of briquettes of urea + FYM, urea + vermicompost and urea + neem cake as source of nitrogen along with varying doses of phosphorus and potassium. The influence of the different levels and sources of $\mathrm{N}$ on nitrogen, phosphorus and potash use efficiency under different treatments were studied. The results revealed that the addition of organics in urea briquettes and deep placement of briquettes exhibited higher nitrogen, phosphorus and potassium use efficiency which might be attributed to slow release of nitrogen, thus reducing the losses and thereby higher nutrients uptake and ultimately higher yield. Nitrogen losses in irrigated rice were significantly influenced by the treatments. The concentration of nitrates and ammonia found in leachates in treatments involving urea+organics briquettes were found significantly lower compared to rest treatments. Application of urea briquettes significantly influenced the available $\mathrm{N}, \mathrm{P}, \mathrm{K}$ in soil at harvest. Overall, urea+FYM briquette application among different sources of fertilizer nitrogen was found most suitable for irrigated rice cultivation system and it also showed higher nitrogen use efficiency as compared to recommended dose of fertilizers. 


\section{Introduction}

Rice (Oryza sativa L.) is one of the most important staple food crops in the world. In Asia, more than two billion people are dependent on rice for their livelihood. Chhattisgarh is popularly known as "Rice Bowl of India" with an area of around 3.68 million hectares and production of 8.20 million tons under rice cultivation during kharif season which contributes $8.65 \%$ acreage and $6.30 \%$, production in India with productivity being $2020 \mathrm{~kg} \mathrm{ha}^{-1}$ in 2013-14 (Anonymous 2015).

To meet the global rice demand, the production has to increase at the compound rate of $1.7 \%$ per year. However, the agricultural input sector has critical impact on the rice productivity of a nation as it influences farmers' success to and use of productivity enhancing input like agrochemicals, fertilizer, and seed. Low agricultural input use is often associated with declining soil fertility, declining yields, and low farmer income. Increased use of fertilizer and improved seeds as well as controlling pests and diseases using pesticides are partially credited with the large increases in agricultural productivity growth.

Nitrogen $(\mathrm{N})$ is the most important nutrient in irrigated rice production (Cassman et al., 1998). Current high yields of irrigated rice are often associated with higher doses of fertilizer $\mathrm{N}$. Nearly 30-40 percent of applied nitrogen is actually utilized by the crop; even with the best agronomic practices and strictly controlled conditions the recovery of nitrogen seldom exceeds 50-60 percent (De Datta et al., 1968 and Aulakh et al., 1992). The efficient use of nitrogenous fertilizer is a challenge due to various losses and increase in fertilizer cost. Availability of nitrogen is a determinant factor for the growth and yield of plants. Lowland rice is noted for the efficient utilization of applied nitrogenous fertilizer as compared to upland condition and this is especially true for top dressed nitrogen.

Nitrogenous fertilizers applied to soil undergo physical, chemical and biological transformation by virtue of enzymes and microbial activity and ultimately become available to crops. Rice plants prefer ammonical form of nitrogen during the early stage irrespective of the source viz. ammonical, nitrate, amide or organic form (Yawalkar et al., 1996). The efficient use of nitrogen is recognized as an important production factor for rice but it has always been a problem to raise the utilization rate of the rice plant and to increase efficiency of absorbed nitrogen for grain production.

The low utilization efficiency of $\mathrm{N}$ fertilizers is attributed to losses like volatilization, denitrification, leaching and surface run-off. These losses can be reduced by management practices like proper timing, rate and modified forms of urea and deep placement of $\mathrm{N}$ fertilizers. Several strategies have been tried to enhance nitrogen use efficiency (NUE) in rice including split $\mathrm{N}$ application, the use of slow release $\mathrm{N}$ fertilizers and nitrification inhibitors (NIs). Deep placement of $\mathrm{N}$ briquette at 8-10 $\mathrm{cm}$ depth of soil can save $30 \% \mathrm{~N}$ compared to Prilled Urea (PU), increases absorption rate, improves soil health and ultimately increases rice yield (Savant et al., 1991). The present study was undertaken to evaluate the effect of PU, $\mathrm{N}$ briquette and $\mathrm{N}$ briquette in combination with organics on $\mathrm{N}$ use efficiency and yield of rice crop.

\section{Materials and Methods}

\section{Site description}

The present investigation was carried out under field conditions during kharif 2017 at the Research cum Instructional Farm, Indira 
Gandhi Krishi Vishwavidyalaya, Raipur (C.G)situated on National highway No. 6 in Eastern part of Raipur city and located between $20^{\circ} 4^{\prime}$ 'North latitude and $81^{\circ} 39^{\prime}$ East longitudes with an altitude of $293 \mathrm{~m}$ above mean sea level. The region comes under dry and sub-humid climatic condition. The average annual rainfall of the area is 1400$1600 \mathrm{~mm}$. The weather data during experimental period was collected from the meteorological observatory located at Labhandi (Indira Gandhi Agricultural University), Krishaknagar, Raipur. Major amount of precipitation occurs between June and December (about 5-6 Months) which is the main rice growing season. The hottest and coolest months are May and December, respectively. Rice variety "Rajeshwari"was used as a test crop.

\section{Experimental soil}

The experimental soil (Vertisol) is fine montmorillonitic, hyperthermic, chromustert, locally called as Kanhar and is identified as Arang II series. It is usually deep, clayey (49 $\%$ ), dark brown to black in colour and neutral to alkaline in reaction due to presence of lime concentrations. The soil occurs on mid land position of landscape in Chhattisgarh, is deep and hence has good water holding capacity. The physico-chemical properties of the experimental soil are presented in Table 1.

\section{Experiment design}

The experimental details are as follows:-

\begin{tabular}{|l|l|}
\hline Location & $\begin{array}{l}\text { Instructional cum } \\
\text { Research Farm, I.G.K.V. } \\
\text { Raipur }\end{array}$ \\
\hline Soil Type & Vertisols \\
\hline Season & Kharif 2017 \\
\hline Crop & Rice \\
\hline Variety & Rajeshwari \\
\hline Treatment & $\mathbf{1 1}$ \\
\hline
\end{tabular}

\begin{tabular}{|l|l|}
\hline Design & $\begin{array}{l}\text { Randomized complete } \\
\text { block design }\end{array}$ \\
\hline Replications & Four \\
\hline Net Plot size & $\mathbf{7 m} \times 2 \mathrm{~m}\left(14 \mathrm{~m}^{2}\right)$ \\
\hline Spacing & $20 \mathrm{~cm} \times 10 \mathrm{~cm}$ \\
\hline RDF & $\begin{array}{l}100: 60: 40 \mathrm{~kg} / \mathrm{ha}(\mathrm{N}: \\
\left.\mathrm{P}_{2} \mathrm{O}_{5}: \mathrm{K}_{2} \mathrm{O}\right)\end{array}$ \\
\hline
\end{tabular}

\section{Treatment details}

It is given in Table 2 .

\section{Fertilizer application}

The recommended dose of fertilizer phosphorus and potassium @ 60:40 kg/ha $\left(\mathrm{P}_{2} \mathrm{O}_{5}: \mathrm{K}_{2} \mathrm{O}\right)$ was applied to the respective plots as per requirement (on dry weight basis) in the form of SSP and MOP as basal dose at the time of planting. Considering recommended dose of nitrogen @ $100 \mathrm{~kg} / \mathrm{ha}$. using urea onethird nitrogen was applied as basal dose, another one-third applied at maximum tillering stage and remaining one-third nitrogen was applied at panicle initiation stage.

\section{Urea briquettes application}

\section{Formation of urea briquette}

Urea briquettes were manufactured by physical modification of ordinary urea fertilizer. Its nature and properties are similar to that of urea but it manufactured in pillow shaped structure and condensed with some conditions for slow hydrolysis. Weight of each briquette is $2.5 \mathrm{~g}$ with $46 \% \mathrm{~N}$ content similar to that of PU.

\section{Formation of Urea briquette with organics} (FYM, neem cake, vermicompost)

These briquetteswere prepared in similar way like plain urea briquettes but with some modification that $25 \%$ volume were replaced 
by organics (FYM, neem cake, vermicompost). Weight of urea+FYM briquettes was $2.2 \mathrm{~g}$, urea+neem cake briquettes was $2.3 \mathrm{~g}$ and urea+vermicompost briquettes was $2.2 \mathrm{~g}$ per briquette (Figure 1).

\section{Deep placement of urea briquettes}

Full dose of Urea briquettes on weight basis were applied after 10 days of transplanting. For N application through USG @ 100, 75 and 50 percent RDF, one USG of $2.4 \mathrm{~g}$ size was employed for every five to six (avg.5.5) hills, seven to eight (avg. 7.3) hills and 11 hills, respectively. In case of urea briquette with organics (FYM, neem cake, vermicompost) one briquette was employed for every five to six (avg.5.5) hills (Figure 2). The granules were deep placed in the puddled soil by hand and leveled immediately after placement.

\section{Statistical analyses}

The data collected from field observations and those recorded in laboratory were subjected to statistical analysis by standard analysis of variance technique. For significant treatment effects, standard error of means (SEm \pm ) and critical differences were calculated at 5 per cent level of significance.

\section{Observations taken}

Yield: In the experiment various growth and yield attributing characters viz., number of panicles $\mathrm{m}^{-2}$,number of grains per panicle, test weight of 1000 grain andgrain and straw yieldswere recorded.

Plant analysis: The dried and powdered form of straw and grain samples were analyzed for total $\mathrm{N}, \mathrm{P}$ and $\mathrm{K}$ contents.

Soil analysis: The initial soil sample and plot wise samples collected at harvest were collected and analyzed for chemical properties like $\mathrm{pH}, \mathrm{EC}, \mathrm{OC}$, and contents of available $\mathrm{N}$, $\mathrm{P}$ and $\mathrm{K}$ following standard procedures.

Nutrient uptake (kg ha $\left.{ }^{-1}\right): \mathrm{N}, \mathrm{P}$ and $\mathrm{K}$ uptake by the rice crop were computed from their respective elemental concentration in seed and straw of the crops.

Nutrient uptake $\left(\mathrm{kg} \mathrm{ha}^{-1}\right) \quad=$

$$
\text { Yields }\left(\mathrm{kg} \mathrm{ha}^{-1}\right) \mathrm{x} \text { content }(\%)
$$

100

Nutrient use efficiency (\%): The other parameters viz; NUE of N, P, K, and Nutrient Recovery Efficiency (NRE) were calculated according to Ciampitti and Vyn(2011) is given below:

$\operatorname{NUE}(\%)=$

Uptake from treated plot - uptake from control plot

Applied fertilizer X 100

\section{Results and Discussion}

\section{Effect of different Nitrogen levels and sources on yield in irrigated rice}

In the experiment grain and straw yieldswere recorded, the results are presented in the following table 3 and figure 3 . The results revealed that all recorded yield attributes of rice were significantly influenced by the different levels and sources of nitrogen. The grain yield was found significantly superior in treatment T9 [Urea+FYM briquettes (75:25 vol. basis $)+100 \%$ PK(RDF)] (54.64 q/ha) when compared to treatment $\mathrm{T} 1, \mathrm{~T} 2, \mathrm{~T} 3, \mathrm{~T} 5$, T6, T7 and T8 whereas, it was statistically at par to T4, T10, and T11. The lowest grain yield $(40.75 \mathrm{q} / \mathrm{ha})$ was recorded in treatment T5. The highest straw yield 80.54 q./ha was 
found in treatment $\mathrm{T} 9$ and the lowest straw yield 65.79 q./ha was recorded in treatment T5. Broadcasting of prilled urea tends to increase various losses of nitrogen therefore recorded lower yield compared with deep placement of briquettes which induces slow release of nutrient reducing the losses and thereby higher nutrient uptake and produces higher yield. These findings collaborate well with the observations found by Islam et al., (2011).Similarly,Kapoor et al., (2008) also observed that significantly higher grain yield was observed with deep placement of NPK briquette compared to 43 broadcast applications.

\section{Effect of different nitrogen levels and sources on nutrient uptake}

Results in table 4 and figure 4 indicate that the total $\mathrm{N}, \mathrm{P}$ and $\mathrm{K}$ uptake in grain and straw of paddy varied significantly due to application of different nitrogen levels and sources in the form of PU, USG, and urea + organics briquettes.

\section{Nitrogen uptake}

The total $\mathrm{N}$ uptake ranged from 69.77 to $102.10 \mathrm{~kg} / \mathrm{ha}$. The highest value of total $\mathrm{N}$ uptake102.10 $\mathrm{kg} / \mathrm{ha}$. was observed in T9[Urea+FYM briquettes(75:25 vol. basis)+ $100 \% \mathrm{PK}(\mathrm{RDF})]$ followed by $\mathrm{T} 4[100 \% \mathrm{~N}$ through USG+ $100 \% \mathrm{PK}$ (RDF)] whereas minimum total $\mathrm{N}$ uptake was recorded as $69.77 \mathrm{~kg} / \mathrm{ha}$. inT5 [50\% N (RDF) through urea $+50 \% \mathrm{PK}(\mathrm{RDF})]$. The overall observations revealed that the $\mathrm{N}$ uptake value recorded in treatment $\mathrm{T} 9$ was at par to that of treatments T10, T11 and T4 and significantly superior to rest treatments T1, T2, T3, T5, T6, T7 and T8.

\section{Phosphorus uptake}

The total P uptake by grain and straw ranged from 23.64 to $35.50 \mathrm{~kg} / \mathrm{ha}$. The highest value of total P uptake $35.50 \mathrm{~kg} / \mathrm{ha}$. Was recorded in
T9 [Urea+FYM briquettes (75:25 vol. basis) + $100 \%$ PK(RDF)] followed by $\mathrm{T} 4[100 \% \mathrm{~N}$ through USG+ $100 \% \mathrm{PK}$ (RDF)] whereas minimum $\mathrm{P}$ uptake was recorded as 23.64 $\mathrm{kg} / \mathrm{ha}$. In $\mathrm{T} 5[50 \% \mathrm{~N}(\mathrm{RDF})$ through urea + $50 \% \mathrm{PK}(\mathrm{RDF})]$.

Observations revealed that $\mathrm{P}$ uptake value recorded in treatment $\mathrm{T} 9 \mathrm{~T} 10, \mathrm{~T} 11$ and $\mathrm{T} 4$ and significantly superior to rest treatments $\mathrm{T} 1, \mathrm{~T} 2$, T3, T5, T6, T7 and T8.

\section{Potassium uptake}

The total K uptake by grain and straw ranged from 100.52 to $131.98 \mathrm{~kg} / \mathrm{ha}$. The highest value of total $\mathrm{K}$ uptake $131.98 \mathrm{~kg} / \mathrm{ha}$. was observed in T9 [Urea+FYM briquettes (75:25) $+100 \% \mathrm{PK}(\mathrm{RDF})]$ followed by $\mathrm{T} 4[100 \% \mathrm{~N}$ through USG $+100 \% \mathrm{PK}(\mathrm{RDF})]$ whereas minimum $\mathrm{K}$ uptake was recorded as 100.52 $\mathrm{kg} / \mathrm{ha}$. In $\mathrm{T} 5[50 \% \mathrm{~N}(\mathrm{RDF})$ through urea + $50 \% \mathrm{PK}(\mathrm{RDF})]$.

Observations revealed that the K uptake value recorded in treatment T9 was at par to that of treatments $\mathrm{T} 11$ and $\mathrm{T} 4$ and significantly superior to rest treatments $\mathrm{T} 1, \mathrm{~T} 2, \mathrm{~T} 3, \mathrm{~T} 5, \mathrm{~T} 6$, $\mathrm{T} 7$ and $\mathrm{T} 8$.

The treatment $\mathrm{T} 9$ performed better due to slow and regular release effect asbriquettes with organics provide better nutrient use efficiency and minimum nutrient losses so that plant can easily uptake nutrient in their critical growth period.

Darade and Bankar (2009) found similar level of nitrogen uptake by the deep placement of fertilizer briquettes. Similar result was reported by Mishra et al., (1999), Laxminarayana (2006), Gupta et al., (2006).

Chesti et al., (2015), where application of recommended dose of NPK and USG along with organic sources improved nutrient uptake by rice. 
Effect of different nitrogen levels and sources on nutrient use efficiency

Nutrient use efficiencyrepresents the response of rice plant in terms of grain yield to applied nutrient i.e. $\mathrm{N}, \mathrm{P}$ and $\mathrm{K}$ fertilizer. The data on nutrient use efficiency is presented in table 5 and figure 5 .

\section{Nitogen use efficiency}

The highest value $(68.8 \%)$ of Nitrogen use efficiency (NUE) was obtained in T9 [Urea + FYM briquettes $(75: 25$ vol. basis $)+$ $100 \% \mathrm{PK}(\mathrm{RDF})]$ followed by $\mathrm{T} 1$ whereas minimum value $(34.5 \%)$ of NUE was observed in $\mathrm{T} 7 \quad[100 \% \mathrm{~N}(\mathrm{RDF})+$ $50 \% \mathrm{PK}(\mathrm{RDF})]$. The urea + organics briquettes treated plots i.e. treatments $\mathrm{T} 9, \mathrm{~T} 10$ and $\mathrm{T} 11$ revealed much higher NUE compared to the PU treated plot i.e treatments $\mathrm{T} 6, \mathrm{~T} 7$ and $\mathrm{T} 8$. These results indicated that application of urea+organics briquettes and USG in rice field decrease the losses of $\mathrm{N}$ and save the fertilizer, leading to efficient uptake and utilization of applied N.

\section{Phosphorus use efficiency}

The highest value (27.6\%) of Phosphorus use efficiency (PUE) was obtained in T3[100\%USG + FYM(75:25 Vol. basis) $+100 \%$ PK (RDF)] followed by T2 whereas minimum value (13.2\%) of PUE was observed in $\mathrm{T} 5 \quad[50 \% \mathrm{~N}(\mathrm{RDF})+50 \% \mathrm{PK}(\mathrm{RDF})]$. The urea+FYM briquettes treated plots i.e. treatments T9, T10, T11 and the plots treated with USG i.e. T4 had much higher PUE compared to the PU treated plot i.e treatments T8.

\section{Potassium use efficiency}

The highest value $(89.9 \%)$ of Potassium use efficiency (KUE) was obtained in T3[100\%N through USG+ $100 \% \mathrm{PK}(\mathrm{RDF})$ followed by
$\mathrm{T} 2$ whereas minimum value $(45.4 \%)$ of KUE was observed in $\mathrm{T} 8[100 \% \mathrm{~N}(\mathrm{RDF})$ through urea+100\% PK(RDF)]. The urea+FYM briquettes treated plots i.e. treatments $\mathrm{T} 9$, T10, T11 and the plots treated with USG i.e. treatments $\mathrm{T} 4$ had much higher KUE compared to the PU treated plot i.e. treatments T8.

Similar findings were reported by Jena et al., (2003). Mishra et al., (1999) observed that the relative efficiency of USG was increased by $40 \%$ over PU. Savant and Stangel (1990) also reported that the agronomic performance and NUE of deep placed USG was found to be superior to that of two or three split applications of urea through RDF.

Phosphorus and Potassium uptake by the crop is a function of $\mathrm{P}$ and $\mathrm{K}$ content respectively and above ground biomass production i.e. yield, so significant variation in uptake was found. This may be due to the synergistic effect of applied different nitrogen sources with $\mathrm{P}$ and $\mathrm{K}$ uptake resulting in varied PUE and KUE with applied different nitrogen levels. These results are similar to the findings of Laxminarayana (2006), Singh et al., (2006), Sunitha et al., (2010) and Chesti et al., (2015).

Effect of different nitrogen levels and sources on nutrient status in soil after harvest

Data presented in table 6 and 7 as well as depicted in figure 6 and 7 indicates the nutrient status in soil after harvest. The data illustrates that available $\mathrm{N}\left(\mathrm{Kg} \mathrm{ha}^{-1}\right)$ in soil at harvest was significantly affected by different $\mathrm{N}$ levels and sources of $\mathrm{N}$ fertilizers. The highest value of available $\mathrm{N}$ was recorded in treatment $\mathrm{T} 4[100 \% \mathrm{~N}$ through USG + $100 \% \mathrm{PK}(\mathrm{RDF})]$ followed by rest treatments involving urea+organics briquettes application i.e. $\mathrm{T} 9, \mathrm{~T} 10$ and $\mathrm{T} 11$ whereas, minimum was observed in T5 [50\% NPK 
(RDF)]. Similarly available $\mathrm{P}$ and $\mathrm{K}\left(\mathrm{Kg} \mathrm{ha}^{-1}\right)$ in soil at harvest were significantly influenced by different nitrogen levels and sources of $\mathrm{N}$ fertilizers. The highest value of available $\mathrm{P}$ and $\mathrm{K}$ were recorded in treatments involving urea+organics briquettes i.e. T9[Urea+FYM briquettes $\quad(75: 25)+100 \% \mathrm{PK}(\mathrm{RDF})]$ followed by $\mathrm{T} 10$ and $\mathrm{T} 11$ and lowest value was observed in T5[50\% NPK (RDF)].

Highest $\mathrm{pH}$ value 7.53 was observed in treatment T10 [Urea + vermicompost USG $(75: 25$ vol. basis $)+100 \% \mathrm{PK}(\mathrm{RDF})]$ followed by $\mathrm{T} 8$ and $\mathrm{T} 7$ whereas minimum (7.35) was recorded in $\mathrm{T} 2[75 \% \mathrm{~N}$ through USG + $50 \% \mathrm{PK}(\mathrm{RDF})]$. However, there were no significant effect of treatments on $\mathrm{pH}$ of soil at harvest. Highest EC value $0.178 \mathrm{dSm}^{-1}$ in soil was observed in treatment $\mathrm{T} 8$ $[100 \% \mathrm{~N}(\mathrm{RDF})$ through urea + $100 \% \mathrm{PK}(\mathrm{RDF})]$ followed by $\mathrm{T} 6$ and $\mathrm{T} 4$ whereas minimum EC value $0.153 \mathrm{dSm}^{-1}$ was recorded in $\mathrm{T} 9$ and $\mathrm{T} 1$. Highest value of organic carbon $(0.54 \%)$ was observed in $\mathrm{T} 10$ [Urea+vermi. USG (75:25 vol. basis) + $100 \% \mathrm{PK}(\mathrm{RDF})]$ which was at par with the treatments involving urea+organics briquettes i.e. T9 and T11 whereas it was significantly higher to $\mathrm{OC}$ values found in rest treatments.

Overall it was observed that available N, P, K and $\mathrm{OC}$ in soil at harvest were significantly influenced by different nitrogen levels and sources. This may be because urea+organics briquettes application or USG slowly releases the nitrogen in soil resulting in minimum losses of $\mathrm{N}$ due to volatilization and leaching as well as it also increases the efficiency of nitrogen. Further, nutrient management practices had significant influence on yield, so significant variation in N, P, K uptake and use efficiency was found. These results go in line with the findings of Rodgers (1986), Savant and Stangel (1990) and Choudhury et al., (1997).

Table.1 Treatment details

\begin{tabular}{|c|c|}
\hline Notations & Treatments \\
\hline T1 & $50 \% \mathrm{~N}$ through USG+50\% PK (RDF) \\
\hline T2 & $75 \% \mathrm{~N}$ through USG + 50\% PK (RDF) \\
\hline T3 & $100 \% \mathrm{~N}$ through USG $+50 \%$ PK $(\mathrm{RDF})$ \\
\hline T4 & $100 \% \mathrm{~N}$ through USG+100\% PK (RDF) \\
\hline T5 & $50 \%$ NPK (RDF) \\
\hline T6 & $\begin{array}{l}75 \% \text { N (RDF) through urea }+50 \% \text { PK } \\
\text { (RDF) }\end{array}$ \\
\hline T7 & $\begin{array}{l}100 \% \mathrm{~N}(\mathrm{RDF}) \text { through urea }+50 \% \\
\text { PK(RDF) }\end{array}$ \\
\hline T8 & $\begin{array}{l}100 \% \mathrm{~N}(\mathrm{RDF}) \text { through urea }+100 \% \text { PK } \\
(\text { RDF })\end{array}$ \\
\hline T9 & $\begin{array}{l}\text { Urea + FYM USG (75:25 volume basis)+ } \\
100 \% \text { PK (RDF) }\end{array}$ \\
\hline T10 & $\begin{array}{l}\text { Urea+VermicompostUSG }(75: 25 \text { volume } \\
\text { basis)+100\% PK (RDF) }\end{array}$ \\
\hline T11 & $\begin{array}{l}\text { Urea +Neem cakeUSG (75:25 volume } \\
\text { basis)+100\% PK (RDF) }\end{array}$ \\
\hline
\end{tabular}


Table.2 Physico-chemical properties of experimental soil

\begin{tabular}{|c|c|c|c|}
\hline \multirow{2}{*}{\multicolumn{2}{|c|}{ Particulars }} & Values & Method \\
\hline & \\
\hline 1 & Sand $(\%)$ & 19 & \multirow{3}{*}{ International pipette method (Piper 1966). } \\
\hline 2 & Silt $(\%)$ & 32 & \\
\hline 3 & Clay $(\%)$ & 49 & \\
\hline 4 & Soil textural class & \multicolumn{2}{|l|}{ Clayey } \\
\hline 5 & Bulk density $\left(\mathrm{Mg} \mathrm{m}^{-3}\right)$ & 1.51 & Williams and Steinbergs (1959). \\
\hline \multicolumn{4}{|c|}{ II. Chemical properties } \\
\hline 1 & $\mathrm{pH}(1: 2.5)$ & 7.48 & Glass electrode pH meter Jackson.(1973) \\
\hline 2 & $\mathrm{EC}\left(\mathrm{dSm}^{-1}\right.$ at $\left.25^{\circ} \mathrm{C}\right)$ & 0.16 & Solubridge conductivity method (Black1965). \\
\hline 3 & Organic carbon $(\%)$ & 0.56 & Rapid titration method (Walkley and Black's 1965). \\
\hline 4 & Available $\mathrm{N}\left(\mathrm{kg} \mathrm{ha}^{-1}\right)$ & 199 & Alkaline permanganate method (Subbiah and Asija, 1956). \\
\hline 5 & Available $\mathrm{P}_{2} \mathrm{O}_{5}\left(\mathrm{~kg} \mathrm{ha}^{-1}\right)$ & 14.97 & Sodium bicarbonate (Olsen et al., 1954) \\
\hline 6 & Available $\mathrm{K}_{2} \mathrm{O}\left(\mathrm{kg} \mathrm{ha}^{-1}\right)$ & 386.2 & Ammonium acetate method (Hanway and Heidel 1952). \\
\hline 7 & Available B $\left(\mathrm{mg} \mathrm{kg}^{-1}\right)$ & 1.54 & Berger and Truog (1939) \\
\hline 8 & Available S $\left(\mathrm{kg} \mathrm{ha}^{-1}\right)$ & 17.76 & Williams and Steinbergs (1959). Turbidimetrically. \\
\hline 9 & Available $\mathrm{Fe}\left(\mathrm{mg} \mathrm{kg}^{-1}\right)$ & 14.2 & \multirow{4}{*}{$\begin{array}{l}\text { Lindsay and Norvell (1978) (DiethyleneTriaminePenta Acetic } \\
\text { Acid Method) }\end{array}$} \\
\hline 10 & Available $\mathrm{Zn}\left(\mathrm{mg} \mathrm{kg}^{-1}\right)$ & 1.53 & \\
\hline 11 & Available $\mathrm{Cu}\left(\mathrm{mg} \mathrm{kg}^{-1}\right)$ & 2.21 & \\
\hline 12 & Available $\mathrm{Mn}\left(\mathrm{mg} \mathrm{kg}^{-1}\right)$ & 6.89 & \\
\hline
\end{tabular}

Table.3 Effect of different nitrogen levels and sources on yield in irrigated rice

\begin{tabular}{|c|c|c|}
\hline Treatment & Grain Yield (q/ha) & Straw Yield (q/ha) \\
\hline T1 & 48.28 & 73.07 \\
\hline T2 & 50.18 & 74.75 \\
\hline T3 & 50.40 & 75.23 \\
\hline T4 & 53.57 & 80.54 \\
\hline T5 & 40.75 & 65.79 \\
\hline T6 & 45.54 & 72.59 \\
\hline T7 & 46.61 & 72.62 \\
\hline T8 & 49.68 & 73.25 \\
\hline T9 & 54.64 & 80.71 \\
\hline T10 & 52.86 & 77.63 \\
\hline T11 & 52.69 & 79.04 \\
\hline CD $(\mathbf{P}=\mathbf{0 . 0 5})$ & 3.4576 & 4.3654 \\
\hline
\end{tabular}


Table.4 Influence of different nitrogen levels and sources on Nutrient uptake in irrigated rice

\begin{tabular}{|c|c|c|c|}
\hline \multirow{2}{*}{ Treatment } & \multicolumn{3}{|c|}{ Nutrient Uptake $\left(\mathrm{kg} \mathrm{ha}^{-1}\right)$} \\
\hline T1 & $\mathrm{N}$ & $\mathrm{P}$ & $\mathrm{K}$ \\
\hline T2 & 82.50 & 28.41 & 113.32 \\
\hline T3 & 86.96 & 30.36 & 117.04 \\
\hline T4 & 92.57 & 30.84 & 118.20 \\
\hline T5 & 101.14 & 35.16 & 130.39 \\
\hline T6 & 69.77 & 23.64 & 100.52 \\
\hline T7 & 80.90 & 27.46 & 112.52 \\
\hline T8 & 84.95 & 28.93 & 113.73 \\
\hline T9 & 90.11 & 31.44 & 118.61 \\
\hline T10 & 102.10 & 35.50 & 131.98 \\
\hline T11 & 97.51 & 33.72 & 125.29 \\
\hline CD (P= $\mathbf{0 . 0 5 )}$ & 98.05 & 33.24 & 126.97 \\
\hline & 4.800 & 2.298 & 6.2847 \\
\hline
\end{tabular}

Table.5 Influence of different nitrogen levels and sources on NPK use efficiency (\%) in irrigated rice

\begin{tabular}{|c|c|c|c|}
\hline Treatments & NUE & PUE & KUE \\
\hline T1 & 64.0 & 22.8 & 80.1 \\
\hline T2 & 48.6 & 26.7 & 87.6 \\
\hline T3 & 42.1 & 27.6 & 89.9 \\
\hline T4 & 50.7 & 18.1 & 57.1 \\
\hline T5 & 38.6 & 13.2 & 54.5 \\
\hline T6 & 40.6 & 20.9 & 78.5 \\
\hline T7 & 34.5 & 23.8 & 80.9 \\
\hline T8 & 39.6 & 14.4 & 45.4 \\
\hline T9 & 68.8 & 18.5 & 58.7 \\
\hline T10 & 62.7 & 16.7 & 52.0 \\
\hline T11 & 63.4 & 16.2 & 53.7 \\
\hline
\end{tabular}

* For calculating NUE, PUE and KUE, yield of control was 25 q/ha absolute 
Table.6 Influence of different nitrogen levels and sources on $\mathrm{pH}, \mathrm{EC}$ and Organic carbon in soil after harvest

\begin{tabular}{|c|c|c|c|}
\hline Treatments & $\mathbf{p H}$ & $\mathbf{E C}(\mathbf{d s} / \mathbf{m})$ & $\mathbf{O C}(\mathbf{\%})$ \\
\hline T1 & 7.38 & 0.153 & 0.37 \\
\hline T2 & 7.35 & 0.165 & 0.48 \\
\hline T3 & 7.41 & 0.165 & 0.49 \\
\hline T4 & 7.39 & 0.173 & 0.47 \\
\hline T5 & 7.46 & 0.165 & 0.40 \\
\hline T6 & 7.49 & 0.173 & 0.43 \\
\hline T7 & 7.50 & 0.165 & 0.49 \\
\hline T8 & 7.52 & 0.178 & 0.48 \\
\hline T9 & 7.46 & 0.153 & 0.52 \\
\hline T10 & 7.53 & 0.155 & 0.54 \\
\hline T11 & 7.48 & 0.155 & 0.51 \\
\hline CD (P= 0.05) & 0.291 & 0.028 & 0.085 \\
\hline
\end{tabular}

Table.7 Influence of different nitrogen levels and sources on available NPK in soil after harvest

\begin{tabular}{|c|c|c|c|}
\hline Treatment & $\begin{array}{c}\mathbf{N} \\
\left(\mathrm{kg} \mathrm{ha}^{-1}\right)\end{array}$ & $\underset{\left(\mathrm{kg} \mathrm{ha}^{-1}\right)}{\mathbf{P}}$ & $\begin{array}{c}\mathrm{K} \\
\left(\mathrm{kg} \mathrm{ha}^{-1}\right)\end{array}$ \\
\hline $\mathrm{T} 1$ & 179.55 & 10.15 & 318.78 \\
\hline $\mathrm{T} 2$ & 183.11 & 11.23 & 321.84 \\
\hline $\mathrm{T} 3$ & 205.32 & 12.19 & 340.10 \\
\hline $\mathrm{T} 4$ & 227.21 & 16.15 & 351.85 \\
\hline T5 & 170.14 & 9.54 & 302.35 \\
\hline T6 & 173.95 & 10.31 & 320.59 \\
\hline $\mathrm{T} 7$ & 195.41 & 11.33 & 328.20 \\
\hline $\mathrm{T} 8$ & 202.52 & 15.05 & 341.30 \\
\hline T9 & 220.15 & 18.45 & 385.98 \\
\hline $\mathrm{T} 10$ & 218.33 & 16.98 & 376.80 \\
\hline $\mathrm{T} 11$ & 222.52 & 16.52 & 366.40 \\
\hline $\mathrm{CD}(\mathrm{P}=0.05)$ & 4.80 & 0.73 & 21.75 \\
\hline
\end{tabular}


Fig.1 Urea briquette formation using machine
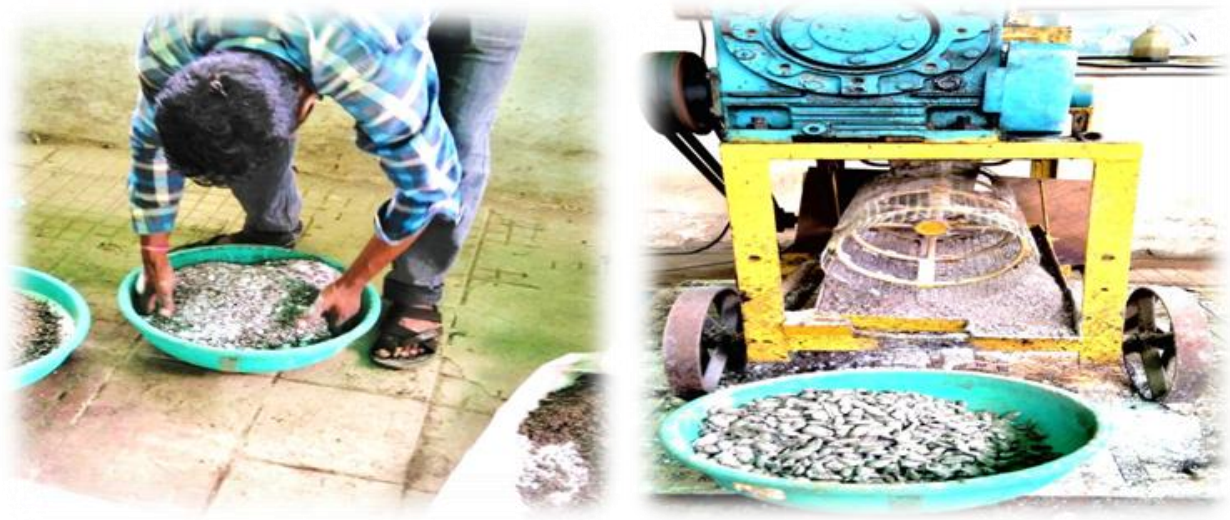

Fig.2 Application layout for (a) Urea briquette with organics and also for $100 \%$ RDF-N through USG (b) 75\% RDF-N through USG (c) 50\% RDF-N through USG (d) Slot of application of USG

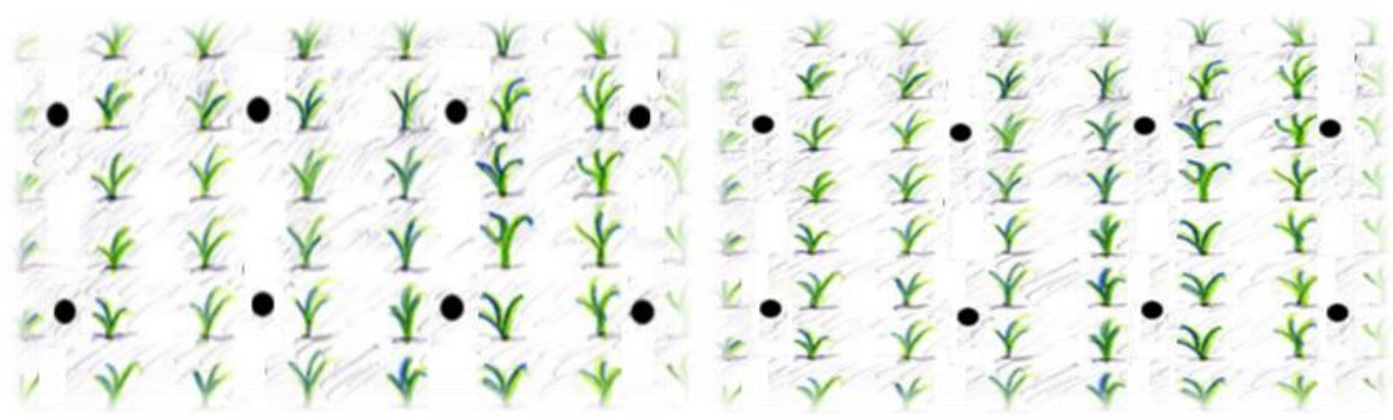

(a)

(b)

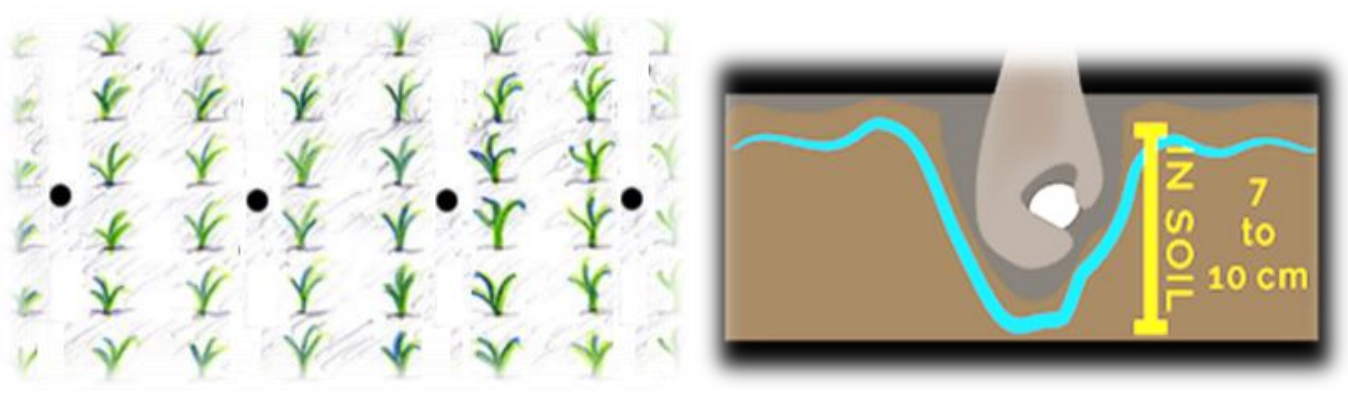

(c)

(d) 
Fig.3 Effect of different nitrogen levels and sources on Yield attributes in irrigated rice

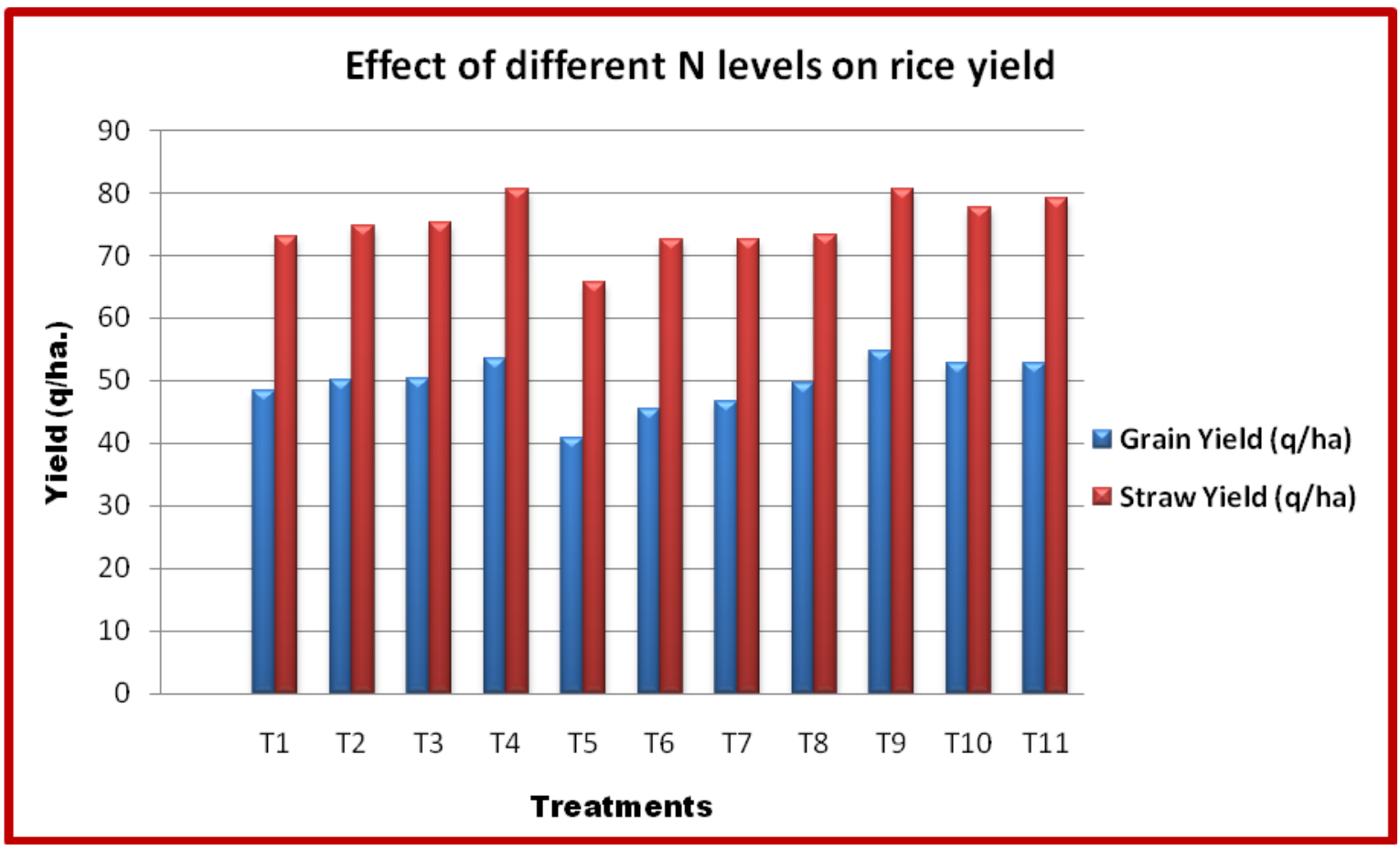

Fig.4 Influence of different nitrogen levels and sources on Nutrient uptake in irrigated rice

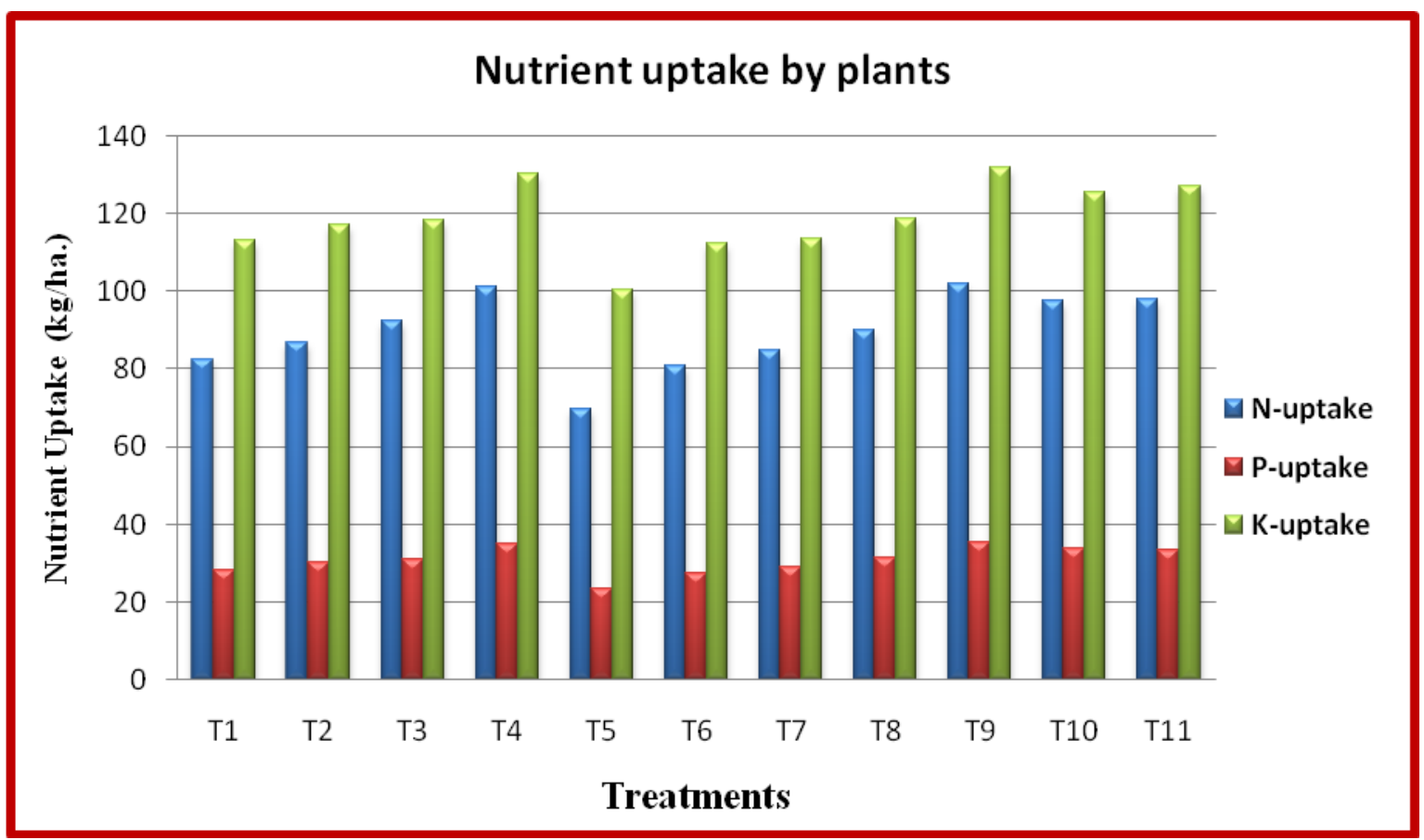


Fig.5 Influence of different nitrogen levels and sources on NPK use efficiency (\%) in irrigated rice

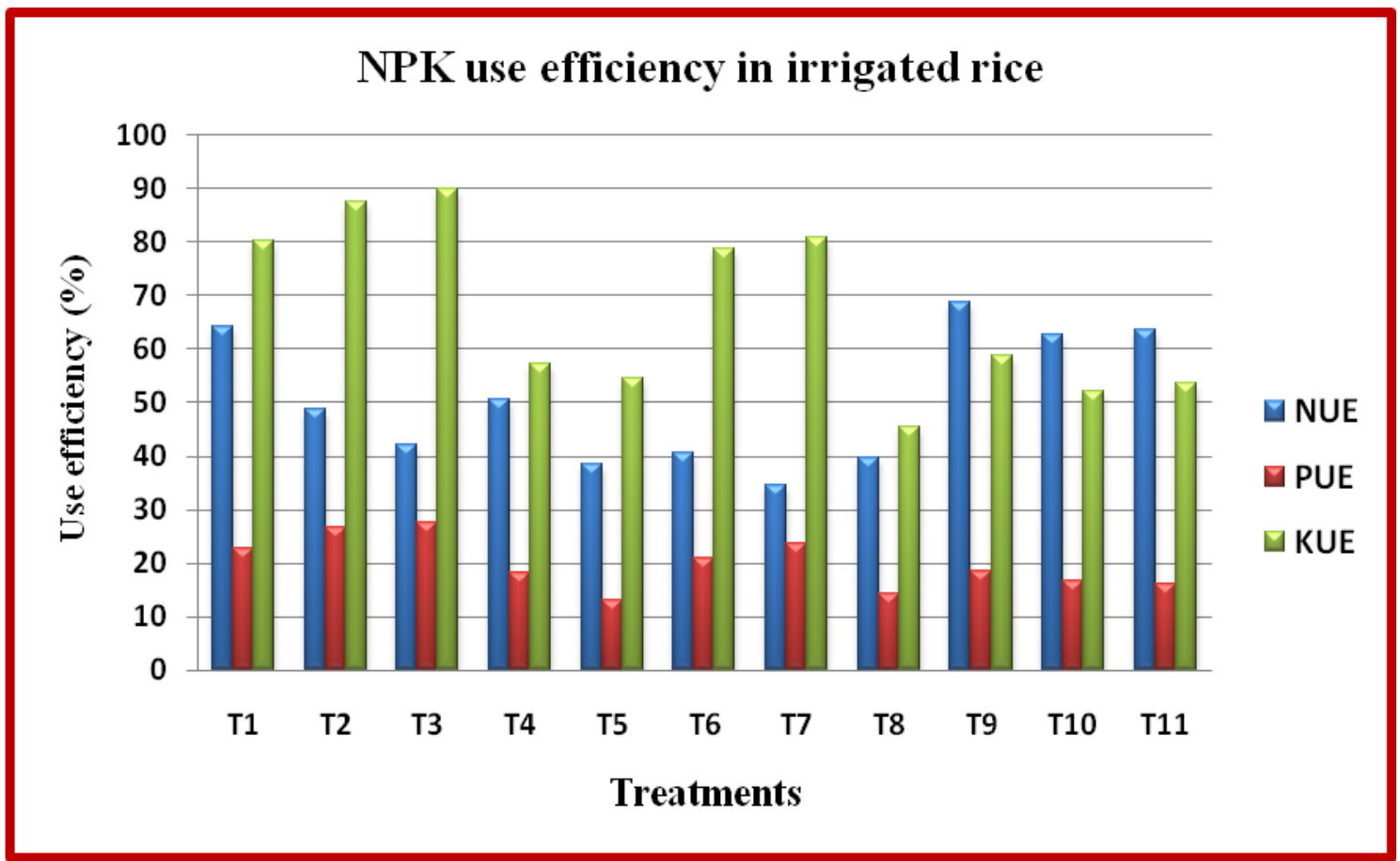

Fig.6 Influence of different nitrogen levels and sources on pH, EC and Organic carbon in soil after harvest

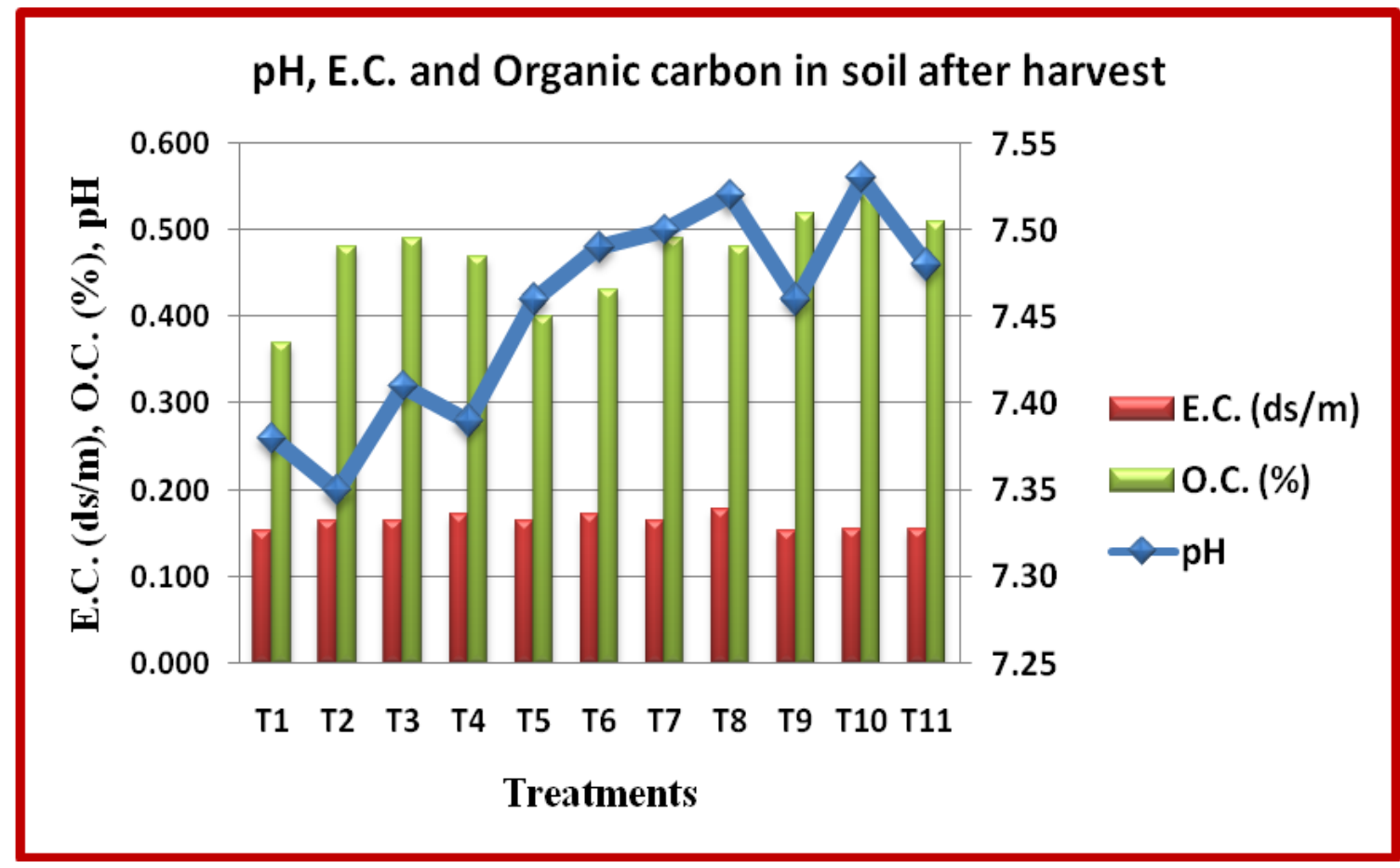


Fig.7 Influence of different nitrogen levels and sources on on available NPK in soil after harvest

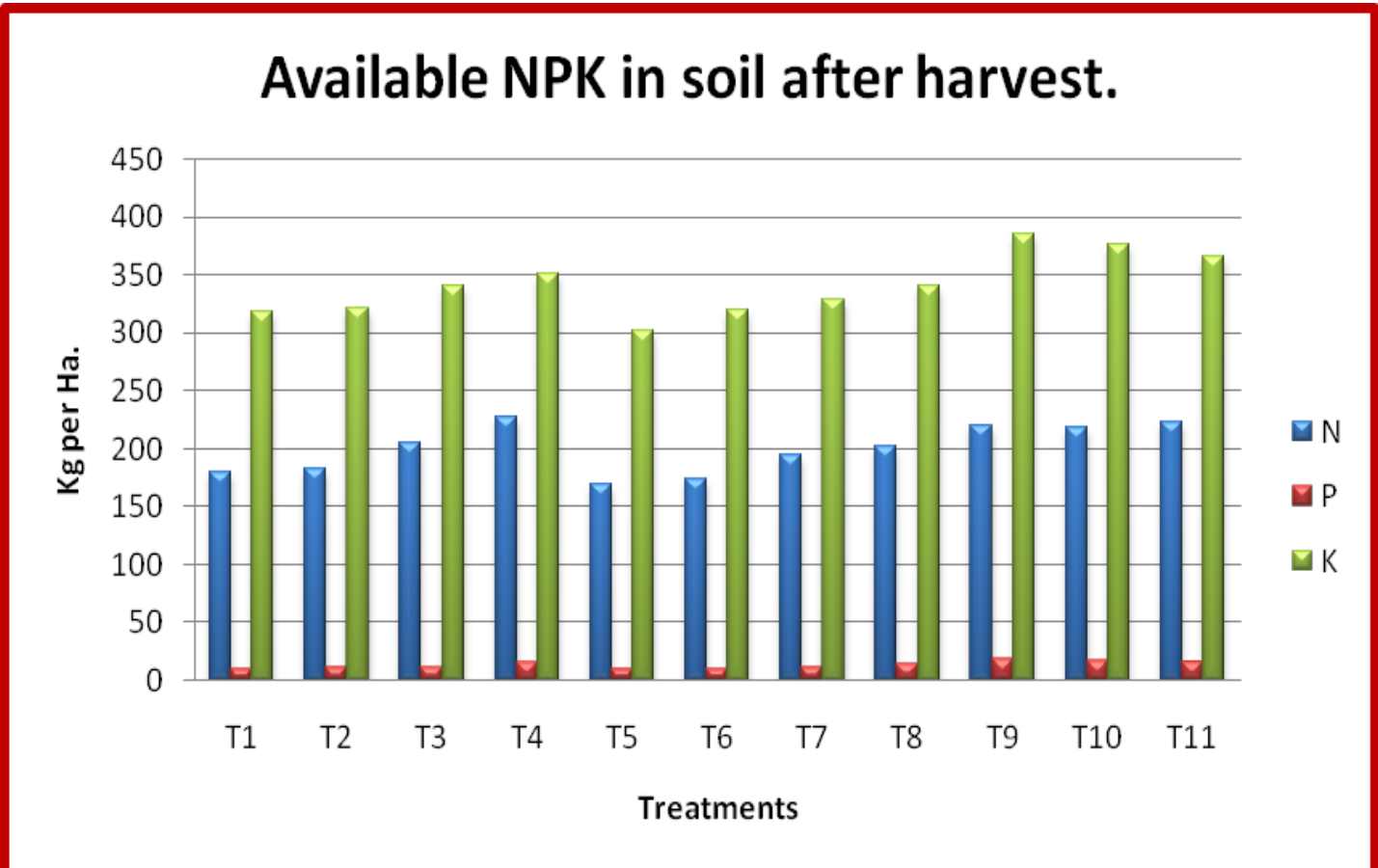

Application of urea+organics briquettes increased crop growth and yield as evidenced by grain and straw yield data. Under irrigated rice, application of urea + FYM briquettes provided better physical, chemical and biological soil condition to plant and improved soil fertility as evidenced by increased soil OC status, available N, P and $\mathrm{K}$; deep placement of briquettes induced slow release of nutrient reducing the losses and improved use efficiency of applied nutrients and thereby higher nutrient uptake as evidenced by better NUE, PUE and KUE.As per the above findings, among different sources of fertilizer nitrogen, Urea + FYM briquette application was found most suitable for irrigated rice cultivation system. More elaborate studies can be carried out to identify other possible natural organic additives and to improve the technology of briquette formation and application in order to reduce the manpower input in the same.

\section{Acknowledgements}

Authors are thankful to the Head, Department of Soil Science and Agricultural Chemistry, Dean, College of Agriculture, Indira Gandhi Krishi Vishwavidyalaya, Raipur (C.G) for providing the necessary facilities in accomplishing the research work.

\section{References}

Ahmed, M., Islam, Md. M. and Paul, S. K. 2005. Effect of nitrogen on yield and other plant characters of local $\mathrm{T}$. aman rice, var. jatai. Research Journal of Agriculture and Biological Sciences, 1(2): 158-161.

Aulakh, M. S., Doran, J. W., and Mosier, A. R. (1992). Soil denitrification: Significance, measurement and effects of management. Adv. Soil Sci. 18:1-57

Bajpai, R.K., Chitale, S., Upadhyay, S.K. and Urkurkar, J.S. 2006. Long-term studies on 
soil physico-chemical properties and productivity of rice-wheat system as influenced by integrated nutrient management in Inceptisol of Chhattisgarh. J.Indian Soc. Soil Sci. 54(1): 24-29.

Cassman, K.G.S., Peng, S., Olk, D.C., Ladha, J.K., Reichardt, W., Doberman, A., Singh, U. 1998. Opportunities for increased nitrogen use efficiency from improved resource management in irrigated rice systems. Field Crops Res. 56:7-38.

Chesti, M.H., Kohli, A., Mujtaba, A., Sofi, J.A., Nazir Q.T., Peer, Q.J.A., Dar, M.A. and Bisati, I.A. 2015. Effect of integrated application of inorganic and organic sources on, soil properties, yield and nutrient uptake by rice (Oryza sativa L.) in intermediate zone of Jammu and Kashmir. J. of the Indian Society of Soil Sci. 63(1):88-92.

Choudhury, A., Bhuiyan, N.I., Hashem, M.A., Matin, M.A. 2009. Nitrogen fertilizers deep placement in wetland rice. Bangladesh Research Publication Journal 2(2): 499-505.

Ciampitti, I.A. and T.J. Vyn. 2012. Physiological perspectives of changes over time in maize yield dependency on nitrogen uptake and associated nitrogen efficiencies: A review. Field Crops Res. 133:48-67.

Das, S. and Singh, T.A. 1994. Nitrogen use efficiency by rice and flood water parameters as affected by fertilizer placement techniques. Journal of Indian Society of Soil Science 42(1):46-50.

Derrick, B.E., Etienne, I., Mathusalem, K. 2017 Comparative Study of Urea in Prilled and Briquette Forms on Rice Production in Marshlands of Rwanda. J Fert. Pest.8: 178.

Gomez, A.K and Gomez, A.A. 1984. Statistical Procedures for Agriculture Res. A wileyInter Sci. Publication. Johan Wiley and Sons, New York.

Hasan, S.M. 2007. Effect of level of urea supergranules on the performance of $\mathrm{T}$. aman rice. M. Sc. Ag. Thesis in Agronomy, BAU, Mymensingh.P:72-85.

Islam, M.S., Rahman, F. and Hossain A.T.M.S. 2011. Effects of NPK Briquette on Rice (Oryza sativa) in Tidal Flooded Ecosystem. The Agriculturists 9(1\&2): 37-43(2011) ISSN-1729-5211 A Scientific Journal of Krishi Foundation.

Jena, D., Misra, C., Bandyopadhyay, K.K. 2003. Effect of prilled urea and urea super granules on dynamics of ammonia volatilization and $\mathrm{N}$ use efficiency of rice. Journal of Indian Society of Soil Science 51(3): 257-261.

Darade, A.B. and K.B. Bankar. 2009. Effect of Urea-DAP briquettes and zinc levels on nitrogen, phosphorus and potassium uptake and yield of hybrid rice. Int. J. Agric.Sci. 5(2):510-512.

Devi Joshna M.C., Anurag, Surekha, K., Bajpai, R.K. and Kumar R. 2017. Studies on Nitrogen use efficiency in irrigated rice as influenced by various sources of Nitrogen. International Journal of Chemical Studies, 5(4): 1278-1281.

Gupta, V., Sharma, R.S., and Vishvakarma, S.K. 2006. Long-term effect of integrated nutrient management on yield sustainability and soil fertility of rice (Oryza sativa)-wheat (Triticum aestivum) cropping system. Indian Journal of Agronomy, 51: 160-164.

Hanway, J. J. and Heidel, H. 1952. Soil analyses methods as used in Iowa State College Soil Testing Laboratory. Iowa Agric, 57: 1-31.

Kapoor, V., Singh, U., Patil, S. K., Magre, H., Shrivastava, L. K., Mishra, V. N., Das, R. O. Samadhiya, V. K., Sanabria J. and Diamond, R. 2008. Rice Growth, Grain Yield and Floodwater Nutrient Dynamics as Affected by Nutrient Placement Method and Rate. Agronomy Journal. 100(3):526-536.

Kumar, A., Meena, R.N., Yadav, L. and Gilotia, Y.K., 2014. Effect of organic and inorganic sources of nutrient on yield, yield attributes and nutrient uptake of rice cv. PRH-10. The Bioscan, 9(2): 595-597. 
Laxminarayana K and Patiram 2006. Effect of integrated use of inorganic, biological and organic manures on rice productivity and soil fertility in Ultisols of Mizoram. J. Indian Soc. Soil Sci. 54(2): 213-220.

Miah, I., Chowdhury, M.A.H., Sultana, R., Ahmed, I. and Saha, B.K. 2012. Effects of prilled urea and urea super granule on growth, yield and quality of BRRI dhan28. J. Agrofor. Environ., 6 (1): 5762.

Mishra, B.K., Mishra, S., Dash, A.K., and Jena, D. 1999. Effect of time for urea super granule (USG) placement on lowland rice. Annals Agricultural Research, 20(4): 443-447.

Olsen, S.R., Cole, C.V. Watnable F.S. and Dean, L.A. 1954. Estimation of available phosphorous in soils by extraction with sodium carbonate. U.S.D.A. Cir. No. 933: 1-10.

Pengfei Li et. al. 2018. Nitrogen losses, use efficiency, and productivity of early rice under controlled-release urea.Journal of Agriculture, Ecosystems \& Environ., 251:78-87.

Piper, C.S. 1966. Soil and Plant Analysis, Hans. Pub. Bombay. Asian Ed. pp. 368-374.

Rodgers, G.A. 1986. Nitrification inhibitors in agriculture. Journal of Environmental Science and Health. Part A: Environmental Science and Engineering. 21 (7):701-722.

Roy, Rinky, Bajpai, R.K. and Bachkaiya, V. 2018. Assessment of urea briquettes in combination with organics on rice productivity under irrigated conditions. Trends in Biosciences Journal.11(30):3612-3614.

Savant, N.K. and Stangel, P.J. 1990. Deep placement of urea super granules in transplanted rice: principles and practices. Fertilizer Research, 25: $1-83$.

Subbaiah, B.V and Asija, G.L. 1956. A rapid procedure of estimation of availablenitrogen in soils.Current Science, 65(7):477-480.

Subbiah, S., Ramanathan, K.M. and Francis, H.J. 1979. Influence of neem cake-coated urea application on the yield and nutrient uptake by IR20 rice. International Rice Commission Newsletter, 28(2):15-19.

Sunitha, B.P., Prakasha, H.C. and Gurumurthy, K.T. 2010. Influence of organics, inorganic and their combinations on availability, content and uptake of secondary nutrients by rice crop (Oryza sativa L.) in Bhadra Command, Karnataka. Mysore Journal of Agricultural Sciences 44(3):509-516.

Yawalkar, K. S., Agrawal, J. P. and Bokde, S. 1996. Commercial nitrogenous fertilizers. Manure and fertilizers, 8(4): 96-97.

Zhang, J., Qin, J., Yao, W., Bi1, L., Lai, T. and $\mathrm{Yu}, \mathrm{X}$. 2009. Effect of long-term application of manure and mineral fertilizers on nitrogen mineralization and microbial biomass in paddy soil during rice growth stages. Plant Soil Env., 55(3): 101-10.

\section{How to cite this article:}

Rinky Roy, R.K. Bajpai, Vinay Bachkaiya, Chandan Kumar Roy, Minakshi Sahu, Neha Padhi and Ankita Tirkey. 2018. Evaluation on Impact of Use of Urea Briquettes in Combination of Organics on Nutrient Use Efficiency in Irrigated Rice. Int.J.Curr.Microbiol.App.Sci. 7(12): 1464-1479. doi: https://doi.org/10.20546/ijcmas.2018.712.174 